\section{A vezetői elégedettség vizsgálata egy mezőgazdasági szervezetben}

\section{Barta Ágnes}

MATÁV Oktatási Igazgatóság, Képzési Központ, Budapest

\section{ÖSSZEFOGLALÁS}

Az eröforrások közül egyedül az emberi eröforrások képesek tevékenységük megtervezésére, megszervezésére, saját és mások teljesitményének befolyásolására, valamint szükség esetén a korrekciók végrehajtására. A szervezeti döntésekben egyrészt meghatározó szerepe van annak, hogy milyen a menedzserek felkészültsége, képzettsége, tapasztalata, milyen képességekkel, kompetenciákkal rendelkeznek (Zoltayné, 1997); másrészt fontos tényezöje a vezetők teljesitményének, hogy milyen szervezetekben, milyen körülmények között dolgoznak, illetve mennyire elégedettek helyzetükkel.

Jelen tanulmány célja a különbözö szintü vezetök elégedettségének vizsgálata a Szerencsi Mezögazdasági Részvénytársaságnál.

\section{Az adatgyüjtés módszere, körüllményei}

A vizsgálat elvégzésének ideje: 2001. január.

A vezetök helyzetének vizsgálatára vonatkozó kérdöiv 40 kérdésböl áll.

A zárt kérdéseknél 1-7-ig terjedö skálán (Likert-féle 7 fokú skála) jelölheti, mennyire ért egyet az adott állitással. (1-egyáltalán nem, 7 -teljes mértékben).

A 40 kérdés 8 témakör köré csoportosul, mellyel feltárhatók azok a gátló tényezök, melyek akadályozólag hatnak a szervezet ideális müködése szempontjából, valamint feltárhatók a szervezet azon erösségei, melyek biztositják a sikeres müködést. Ugyanakkor a kérdöív eredményeinek feldolgozása átfogó képet ad a három vezetöi szint elégedettségéröl.

A 8 témakör: 1. Célok, stratégia, 2. Innovativitás, 3. Vezetés, 4. Együttmüködés, 5. Kommunikáció, 6. Motiváció, 7. Elkötelezettség, identitás, 8. Rugalmas, tanuló szervezet.

Vizsgálati eredmények

A statisztikai elemzés módszere: 2-mintás t-próba.

Témakörök szerinti átlageredmények az egyes vezetői szinteken

\begin{tabular}{|l|r|r|r|}
\hline \multirow{2}{*}{\multicolumn{1}{c|}{ Témakörök }} & \multicolumn{3}{|c|}{$\begin{array}{c}\text { Vezetöi szintek szerinti } \\
\text { átlageredmények }\end{array}$} \\
\cline { 2 - 4 } & $\begin{array}{c}\text { Felsö- } \\
\text { vezetö́k }\end{array}$ & $\begin{array}{c}\text { Közép- } \\
\text { vezetök }\end{array}$ & $\begin{array}{c}\text { Operativ } \\
\text { vezetök }\end{array}$ \\
\hline 1. Célok, stratégia & 6,9 & 5,6 & 4,5 \\
\hline 2. Innovativitás & 6,5 & 4,6 & 4,5 \\
\hline 3. Vezetés & 6,7 & 5,0 & 5,4 \\
\hline 4. Együttmüködés & 6,3 & 5,5 & 4,5 \\
\hline 5. Kommunikáció & 6,1 & 4,7 & 4,5 \\
\hline 6. Motiváció & 5,9 & 4,8 & 3,9 \\
\hline 7. Elkötelezettség, identitás & 6,6 & 6,2 & 6,1 \\
\hline 8. Rugalmas, tanuló szervezet & 6,5 & 5,1 & 4,0 \\
\hline
\end{tabular}

Összefoglalva a szervezet erösségei:

- az elkötelezettség, identitás; a vezetés; a célok ismerete és az együttmüködés témakörökben összpontosulnak;

- a javitandó területek pedig a motiváció; a kommunikáció információáramlás; az innovativitás és a rugalmas tanuló szervezet területén keresendök.

\section{SUMMARY}

Human resource managers are able to plan and organise activities which influence their own and other peoples' performance, and also make necessary corrections on the basis of those performances. Managerial skills, experience, type of abilities and competencies each play a definitive role in organisational decisions. On the other hand, the second determinative factor of managerial performance is the organisation in witch they work.

The goal of my survey was to analyse contentment of different level managers at Szerencsi Agricultural Rt.

\section{Methods of data collection}

I used a questionnaire which contained 40 statements. In filling in responses used a 7-degree scale, responds measuring degree of agreement with the statement. The questionnaire centred around eight subjects with which we can reveal those impeding factors which hinder the ideal functioning of the organisation, and the other hand, also reveals strong points of the organisation and management.

These were: 1. Goals and strategies, 2. Innovation, 3. Management, 4. Co-operation, 5. Communication style, information-gathering, 6. Motivation, 7. Commitment , 8. Learning organisation

In the same questionnaire, I examine the managers' age and gender proportion.

The survey results

Averages for different level managers

\begin{tabular}{|l|r|r|r|}
\multirow{2}{*}{\multicolumn{1}{|c|}{ Topics }} & \multicolumn{3}{|c|}{$\begin{array}{c}\text { Averages for different level } \\
\text { managers }\end{array}$} \\
\cline { 2 - 4 } & $\begin{array}{c}\text { Top } \\
\text { managers }\end{array}$ & $\begin{array}{l}\text { Mid-level } \\
\text { managers }\end{array}$ & $\begin{array}{c}\text { Operative } \\
\text { level } \\
\text { managers }\end{array}$ \\
\hline 1. Goals, strategies & 6.9 & 5.6 & 4.5 \\
\hline 2. Innovation & 6.5 & 4.6 & 4.5 \\
\hline 3. Management & 6.7 & 5.0 & 5.4 \\
\hline 4. Co-operation & 6.3 & 5.5 & 4.5 \\
\hline 5. Communication & 6.1 & 4.7 & 4.5 \\
\hline 6. Motivation & 5.9 & 4.8 & 3.9 \\
\hline 7. Commitment & 6.6 & 6.2 & 6.1 \\
\hline 8. Learning organisation & 6.5 & 5.1 & 4.0 \\
\hline
\end{tabular}

In summary, most managers are male and older than 40, but results show as a consequence, that the agricultural sector has become a great opportunity for young experts.

Conclusions:

- Strong points of these organisations can be found in the following areas: commitment, management, goals and strategies, co-operation.

- Organisational impeding factors can be found in the following areas: motivation, communication and flow of information, innovation, learning organisations. 
$\mathrm{Az}$ erőforrások közül egyedül az emberi erőforrások képesek tevékenységük megtervezésére, megszervezésére, saját és mások teljesítményének befolyásolására, valamint szükség esetén a korrekciók végrehajtására. Az elmúlt évtizedekben a hektikus gazdasági élet a mezőgazdaság területén is számos olyan döntést kényszerített ki, melyek stratégiai jelentőségűek. Ezekben a döntésekben egyrészt meghatározó szerepe van annak, hogy milyen a menedzserek felkészültsége, képzettsége, tapasztalata, milyen képességekkel, kompetenciákkal rendelkeznek (Zoltayné, 1997); másrészt fontos tényezője a vezetők teljesítményének, hogy milyen szervezetekben, milyen körülmények között dolgoznak, illetve mennyire elégedettek helyzetükkel.

Ezt a két meghatározó tényezőt, tehát a vezetői kompetenciákat és a vezetők elégedettségét vizsgáltam a Szerencsi Mezőgazdasági Részvénytársaságnál. Ebben a tanulmányban a vezetők elégedettségére vonatkozó vizsgálat eredményeit ismertetem.

\section{A TÁRSASÁG RÖVID BEMUTATÁSA}

A Szerencsi Mezőgazdasági Rt-t a Szerencsi Állami Gazdaság általános jogutódjaként az ÁVÜ alapította 1992. december 31-i fordulónappal. A cégbejegyzés 1993. július 23-án történt meg.

1. táblázat

Tőkeszerkezet (ezer Ft-ban)

\begin{tabular}{|l|c|c|c|c|}
\hline \multicolumn{1}{|c|}{ Megnevezés(1) } & $\begin{array}{c}\mathbf{1 9 9 2 .} \\
\text { év(7) }\end{array}$ & $\begin{array}{c}\mathbf{1 9 9 7 .} \\
\text { év(7) }\end{array}$ & $\begin{array}{c}\mathbf{1 9 9 8 .} \\
\text { év(7) }\end{array}$ & $\begin{array}{c}\mathbf{1 9 9 9 .} \\
\text { év(7) }\end{array}$ \\
\hline Jegyezett tőke(2) & 460.500 & 460.500 & 761.660 & 821.660 \\
\hline Tőketartalék(3) & 412.699 & 525.764 & 574.023 & 631.463 \\
\hline Eredménytartalék(4) & 0 & 322.372 & 573.477 & 818.134 \\
\hline $\begin{array}{l}\text { Mérleg szerinti } \\
\text { eredmény(5) }\end{array}$ & 0 & 250.720 & 244.657 & 190.766 \\
\hline Saját vagyon együtt(6) & $\mathbf{8 7 3 . 1 9 9}$ & $\mathbf{1 . 5 5 9 . 3 5 6}$ & $\mathbf{2 . 1 5 3 . 8 1 7}$ & $\mathbf{2 . 4 6 2 . 0 2 3}$ \\
\hline
\end{tabular}

Forrás: APV Rt.: Társasági ismertetők

Table 1: The value composition of capital (1000 HUF) Naming(1), Subscribed capital(2), Capital reserve(3), Issue reserve(4), Issue by balance-sheet(5), Own capital together(6), year(7)

A részvénytársaság tulajdonosa 93,77\%-ban az Állami Privatizációs és Vagyonkezelő Rt., az 1995. évi XXXIX. tv. szerint a tartósan állami tulajdonban maradó tulajdoni hányad $75 \%$, a jegyzett töke $6,23 \%$ a dolgozói részvény.

A tartós állami tulajdonba sorolás szakmai indokai: Észak-kelet Magyarországon a Szerencsi Mg. Rt. az egyetlen nagy termelési volumennel rendelkező, túlnyomórészt tiszta mezőgazdasági profilú nagyüzem, amely elsősorban állattenyésztésre alapozott tevékenységet folytat. A sertés- és szarvasmarhatartásban, valamint a kalászos növénytermesztésben számottevő biológiai alapok felett rendelkezik. A tevékenységet árunövénytermelés, vetőmag előállítás, keveréktakarmány gyártás és húsipari tevékenység egészíti ki. Ezen adottságaira alapozva 1996-tól részt vesz az Integrációs Termelésfejlesztési Programban. A részvénytársaságot tökeereje, termelési színvonala és szakemberállománya a térség egyik legkiemelkedőbb mezőgazdasági vállalkozásává teszi.

A társaság által használt összes szántóterület átlagos kataszteri tiszta jövedelme nem éri el a hektáronkénti 20 AK-t, de termőhelytöl függően 13$30 \mathrm{AK} /$ ha között váltakozik. A részvénytársaság területei és telephelyei három egységben (Szerencs, Taktaharkány és Abaújszántó körzetében) helyezkednek el.

2. táblázat

Földterületek alakulása

\begin{tabular}{|c|c|c|c|c|}
\hline \multirow[b]{2}{*}{ Müvelési ág(1) } & \multicolumn{2}{|c|}{ Kárpótlás előtt(9) } & \multicolumn{2}{|c|}{$\begin{array}{l}\text { Kárpótlás után } \\
(1997-t o ̋ l)(10)\end{array}$} \\
\hline & $\begin{array}{l}\text { terület } \\
\text { (ha)(11) }\end{array}$ & $\begin{array}{c}\text { kat. tiszta } \\
\text { jöv. } \\
\text { (AK/ha)(12) }\end{array}$ & $\begin{array}{l}\text { terület } \\
\text { (ha)(11) }\end{array}$ & $\begin{array}{l}\text { kat. tiszta } \\
\text { jöv. } \\
(\text { AK/ha)(12) }\end{array}$ \\
\hline Szántó(2) & 5.641 & 19,97 & 2.588 & 20,48 \\
\hline Gyep(3) & 775 & 8,37 & 637 & 8,31 \\
\hline Erdő(4) & 389 & 4,18 & 298 & 4,28 \\
\hline \multicolumn{5}{|c|}{ Egyéb müvelt terület(5) } \\
\hline - nádas(6) & 181 & 6,45 & 161 & 6,17 \\
\hline - fanet(7) & 416 & & 236 & \\
\hline Összesen(8) & 7.402 & 16,26 & 3.920 & 16,47 \\
\hline
\end{tabular}

Forrás: APV Rt.: Társasági ismertetők

Table 2: Composition of area

Line of cultivation(1), Arable land(2), Grass(3), Wood(4), Other cultivated area(5), reeds(6), area planted with trees(7), Sum total(8), Before compensation(9), After compensation (from 1997)(10), area (ha)(11), reg. net income (GC/ha)(12)

A földterületek vázolt alakulása miatt lecsökkent az árunövény-termesztés és az optimálisnál lényegesen nagyobb arányú lett a kukorica termőterület, annak ellenére is, hogy a problémák enyhítésére évente 1.000-1.200 ha szántóterületet vesznek bérbe.

A lecsökkent terület ellenére a társaság állattartó telepei megmaradtak, ezek állatállomány feltöltöttsége optimális, termelési eredményei jó színvonalúak, ezért ezek határozzák meg a társaság jövedelmezőségét.

A dolgozók teljes létszáma: 541 fö, ebből felsővezető: 4 fö, középvezető: 12 fö, operatív vezető: 10 fö.

\section{AZ ADATGYÜJTÉS MÓDSZERE, KÖRÜL- MÉNYEI}

A vezérigazgatóval való egyeztetés után a teljes vezetői réteg számára kiküldtem a vezetők helyzetének vizsgálatára vonatkozó kérdőívet. A kérdőív elején az alábbi bevezető szöveg állt: „, $A z$ alábbi kérdöiv, amelyet valamennyi vállalati vezetőnek megküldtem, a cég jelenlegi helyzetének, belső viszonyainak felmérésére szolgál. A vezetés 
számára lehetőség arra, hogy árnyalja a vállalatról eddig kialakult képet. Az Ön számára lehetőséget nyújt ara, hogy anonimitását megörizve, teljesen nyiltan és öszintén elmondhassa a véleményét arról, milyennek látja a vállalatot ma." - Vagyis már a bevezetésben biztosítottam a megkérdezett vezetőket az anonimitásról, ezzel elösegítve az őszinte válaszadási készséget. A vizsgálat elvégzésének ideje: 2001. január. Minden kiküldött kérdöív (26 db) visszaérkezett, ez a magas válaszadási készség nagy értéke a szervezetnek, tükrözi a témában való érintettséget, a véleménynyilvánítási szándékot, a bevonódást, az esetleges fejlesztés iránti vágyat.

A kérdőív elején szereplő kérdés lehetőséget ad a vezetők nem és korcsoport szerinti eloszlásának vizsgálatára. A válaszadónak neme megjelölése után az életkorára vonatkozóan négy korcsoport közül kellett választania: 20-30 év, 30-40 év, 40-50 év, 50től.

A vezetők helyzetének vizsgálatára vonatkozó kérdőív 40 kérdésből áll.

A zárt kérdéseknél 1-7-ig terjedő skálán (Likertféle 7 fokú skála) jelölheti, mennyire ért egyet az adott állítással. (1 - egyáltalán nem, 7 - teljes mértékben). A kitöltés teljesen anonim. A kérdöív végleges formájának kialakulása két évet vett igénybe, az anyaggal több vizsgálatot is végeztem az ipar és a távközlés területén, valamint a tesztet különböző statisztikai vizsgálatoknak vetettem alá a redundancia kizárása érdekében (tesztanalízis).

A 40 kérdés 8 témakör köré csoportosul, mellyel feltárhatók azok a gátló tényezők, melyek akadályozólag hatnak a szervezet ideális működése szempontjából, valamint feltárhatók a szervezet azon erősségei, melyek biztosítják a sikeres müködést. Ugyanakkor a kérdőív eredményeinek feldolgozása átfogó képet ad a három vezetői szint elégedettségéről. A kérdőív egyes témaköreihez tartozó konkrét kérdések ismertetése nagyon terjedelmes lenne, ezért csak a témaköröket elemzem.

\section{A 8 témakör a következő:}

1. Célok, küldetés, stratégia (1-5. kérdés)

A szervezetek létezésének, müködésének indoka a célok elérésére való törekvés. A szervezeti energiák szétforgácsolódásának kiküszöbölése érdekében fontos tényező, hogy a vezetők tisztában legyenek a szervezeti célokkal, és azzal, hogy számukra mi a teendő azok teljesítése érdekében. Ezek a célok akkor tudnak mozgósító erejüek lenni, ha a tagság elfogadja azokat, azonosulni tud velük, ellenkező esetben a tevékenységek nem kívánt irányokat vesznek, sőt előfordulhat, hogy a célok tisztázatlansága miatt az erők egymás ellen hatnak (Beckhard-Harris, 1989).

2. Innovativitás (6-10. kérdés)

$\mathrm{Az}$ innovativitás a változás és a fejlődés érdekében a jobb megoldások és alkalmazások bevezetéséhez szükséges kreatív erőfeszítés és cselekvés (French-Bell, 1995). Mint ilyen eltérö értéket képvisel a különböző szervezetek életében, hiszen a stabil környezetben müködő szervezetek nem akarnak állandóan változni. Nem így a dinamikus környezetben tevékenykedő szervezetek, amelyek fennmaradása függ innovációs potenciáljuktól. Napjainkban az állandó fejlődési és változási kényszer megnöveli az innováció szerepét a vállaltokban.

3. Vezetés (11-15. kérdés)

A vezetés témakörében a vezetö-beosztott kapcsolatot vizsgáltam. A vezetö-beosztott kapcsolatra vonatkozó kérdéseink a vezetői figyelem - visszajelzés - értékelési szempontok ismerete - nyilvános dicséret, valamint a vezetővel való kapcsolat nyitottsága, bizalmi szintje témaköröket ölelték fel.

4. Együttmüködés (16-20. kérdés)

Együttműködés nélkül elképzelhetetlen sikeres szervezeti müködés. Az együttmüködés vizsgálata kiterjed a munkatársak közötti együttmüködés és a szervezeti egységek közötti együttmüködés vizsgálatára. Ebben a kérdéskörben vizsgáltam a konfliktusok kezelésének módját is a szervezetben.

5. Kommunikációs stílus, információáramlás (2125. kérdés)

A szervezeti hatékonyság fontos tényezője, hogy zökkenőmentes legyen az információáramlás a szervezetben, és egyensúlyban müködjenek a formális és informális kommunikációs csatornák. Elengedhetetlen, hogy mindenki időben jusson hozzá a munkájához szükséges pontos információkhoz, megfelelő legyen a kommunikációs stílus.

6. Motiváció (26-32. kérdés)

A motivációs szint vizsgálatához Herzberg kéttényezős modelljére támaszkodtam: Herzberg szerint „motivátor”-ok azok a tényezők, amivel a teljesítmény hosszú távon növelhető, pl. teljesítmény, elismerés, maga a végzett munka, felelősség, előrejutás. A ,higiénés” tényezők, vagy más néven „fenntartók” azok a tényezők, melyekkel a teljesítményt és az elégedettséget növelni ugyan nem lehet, de meglétük csökkenti az elégedetlenséget és növeli a munkahelyhez való ragaszkodást (pl.: szervezeti politika és irányítás, kapcsolat a vezetőkkel beosztottakkal, fizetés stb.) (Herzberg, 1985).

7. Elkötelezettség, identitás (33-35. kérdés)

Szervezeti kultúrán az uralkodó értékmintákat, meggyőződéseket, elvárásokat, normákat, tevékenységeket, kölcsönhatásokat és érzéseket, valamint ezek megjelenési formáit értjük. A kultúra magába foglalja az informális cselekedeteket és kölcsönhatásokat, normákat, értékeket, érzelmeket (Beckhard-Harris, 1989).

8. Rugalmas, tanuló szervezet (36-40. kérdés) „A tanuló szervezetek azok, amelyek a szervezet tagjainak egyéni tudását eredeti módon képesek kombinálni és ezzel a szervezet szintjén új eredeti tudássá ötvözni." (Senge, 1998).

A szervezeti tanulás egy folyamat, amelynek során a szervezet tudást halmoz föl, ezt rögzíti és elterjeszti a szervezetben. A megszerzett tudás 
közös érték, ezért biztosítani kell, hogy ahhoz a szervezet minden tagja hozzáférhessen, és felhasználhassa. A versenyelőnyt az jelenti, hogy a megszerzett tudást a szervezet hogyan képes alkalmazni és kezelni.

\section{EREDMÉNYEK, KÖVETKEZTETÉSEK}

A nem szerinti megoszlás eredményei szerint az Rt. teljes vezetői körében mindössze két nő dolgozik, ezek közül az egyik a közép, a másik pedig az operatív vezetői körből került ki. Az Rt. dolgozóit vizsgálva is nagyon magas a férfiak aránya, összehasonlítva ezt más mezőgazdasági vállaltok helyzetével, az eredmény összefüggésben lehet a mezőgazdasági szektor elférfiasodásának tendenciájával.

Az egyes vezetői szinteken a korcsoport szerinti megoszlást a 3., 4., és 5. táblázat mutatja.

3. táblázat

A felsővezetők korcsoport szerinti megoszlása

\begin{tabular}{|l|r|c|c|c|}
\hline & \multicolumn{4}{|c|}{ Korcsoportok(1) } \\
\cline { 2 - 5 } & $\begin{array}{r}20-30 \\
\text { év(2) }\end{array}$ & $\begin{array}{c}30-40 \\
\text { év(2) }\end{array}$ & $\begin{array}{c}40-50 \\
\text { év(2) }\end{array}$ & $\begin{array}{c}50 \text { év } \\
\text { fölött(3) }\end{array}$ \\
\hline Vezetők száma (fö)(4) & - & - & 1 & 3 \\
\hline
\end{tabular}

Table 3: Top managers' age distribution

Age group(1), year(2), above 50 year(3), Number of managers (person)(4)

A középvezetők korcsoport szerinti megoszlása

4. táblázat

\begin{tabular}{|l|r|c|c|c|}
\hline & \multicolumn{4}{|c|}{ Korcsoportok(1) } \\
\cline { 2 - 5 } & $20-30$ & $30-40$ & $40-50$ & 50 év \\
& $\operatorname{év}(2)$ & év(2) & év(2) & fölött(3) \\
\hline Vezetők száma (fö)(4) & - & - & 5 & 7 \\
\hline
\end{tabular}

Table 4: Mid-level managers' age distribution

Age group(1), year(2), above 50 year(3), Number of managers (person)(4)

5. táblázat

Az operatív vezetők korcsoport szerinti megoszlása

\begin{tabular}{|l|r|c|r|r|}
\hline & \multicolumn{4}{|c|}{ Korcsoportok(1) } \\
\cline { 2 - 5 } & $\begin{array}{c}20-30 \\
\text { év(2) }\end{array}$ & $\begin{array}{c}30-40 \\
\text { év(2) }\end{array}$ & $\begin{array}{c}40-50 \\
\text { év(2) }\end{array}$ & $\begin{array}{c}50 \text { év } \\
\text { fölött(3) }\end{array}$ \\
\hline Vezetók száma (fó)(4) & 2 & 6 & 1 & 1 \\
\hline
\end{tabular}

Table 5: Operative level managers' age distribution

Age group(1), year(2), above 50 year(3), Number of managers (person)(4)

A korcsoport szerinti megoszlás eredményeiből látható, hogy az Rt. vezetöinek döntő többsége a 40 évesnél idősebb korcsoportba tartozik, különösen igaz ez a felső- és középvezetői szinten, ahol ez a vezetők 100\%-át érinti. Ezekből az eredményekből az látszik, hogy a szakmai tapasztalat az Rt. vezetésében még mindig a legnagyobb érték, a fiatalos lendület, az energia, az egyetemen oktatott új ismeretek csak másodlagos értékként jöhetnek számba. Ha a vállalat célja, hogy az utóbb említett értékek is érvényre jussanak, akkor érdemes a fiatal szakemberek számára egy karrier-tervezési és karrier-menedzselési rendszer kialakítását megfontolni.

Biztató, hogy az operatív vezetői szinten ez az arány változik, itt a vezetők többsége a 30-40 éves korcsoportba tartozik ( 6 fö a tizenkettöböl). Ebből arra lehet következtetni, hogy a mezőgazdasági szektor egyre inkább perspektívát jelent az egyetemről kikerülő fiatal szakemberek számára is.

$\mathrm{Az}$ adatok statisztikai feldolgozását 2-mintás t-próba segítségével végeztem. Az egyes témakörökhöz tartozó kérdések átlagaiból egy-egy közös átlagszámot képeztem a vezetői szintek szerint, ezek vannak feltüntetve a 6. táblázatban és az elemzésben szereplő adatok is innen származnak.

Témakörök szerinti átlageredmények az egyes vezetői 6. táblázat szinteken

\begin{tabular}{|l|r|r|r|}
\hline \multirow{2}{*}{ Témakörök(1) } & \multicolumn{3}{|c|}{$\begin{array}{c}\text { Vezetői szintek szerinti } \\
\text { átlageredmények(10) }\end{array}$} \\
\cline { 2 - 4 } & $\begin{array}{c}\text { Felsö- } \\
\text { vezetök } \\
(11)\end{array}$ & $\begin{array}{c}\text { Közép- } \\
\text { vezetők } \\
(12)\end{array}$ & $\begin{array}{c}\text { Operatív } \\
\text { vezetők } \\
(13)\end{array}$ \\
\hline 1. Célok, stratégia(2) & 6,9 & 5,6 & 4,5 \\
\hline 2. Innovativitás(3) & 6,5 & 4,6 & 4,5 \\
\hline 3. Vezetés(4) & 6,7 & 5,0 & 5,4 \\
\hline 4. Együttmüködés(5) & 6,3 & 5,5 & 4,5 \\
\hline 5. Kommunikáció(6) & 6,1 & 4,7 & 4,5 \\
\hline 6. Motiváció(7) & 5,9 & 4,8 & 3,9 \\
\hline 7. Elkötelezettség, identitás(8) & 6,6 & 6,2 & 6,1 \\
\hline 8. Rugalmas, tanuló szervezet(9) & 6,5 & 5,1 & 4,0 \\
\hline
\end{tabular}

Table 6: Averages for different level managers

Topics(1), 1. Goals, strategies(2), 2. Innovation(3), 3. Management(4), 4. Co-operation(5), 5. Communication(6), 6. Motivation(7), 7. Commitment(8), 8. Learning organisation(9), Averages for different level managers(10), Top managers(11), Mid-level managers(12), Operative level managers(13)

Általában megállapítható, hogy a témakörök mindegyikében viszonylag magas átlagértékek születtek és ez a megállapítás mindhárom vezetői szintre igaz. Itt is megfigyelhető az az általános tendencia, hogy az átlagértékek a felsőtől az operatív szint felé haladva általában csökkenő tendenciát mutatnak.

1. A célok, stratégia ismerete témában mindhárom vezetői rétegnél magas átlagértékeket kaptam $(6,9 ; 5,6 ; 4,5)$. Az operatív szint felé haladva az értékek csökkenése figyelhető meg, és a felső és operatív szintek átlagai között szignifikáns különbség érzékelhető. $\mathrm{Az}$ operatív szint válaszaiból az derül ki, hogy azt pontosan látják, hogy a saját munkájukkal hogyan járulnak hozzá a szervezeti célok eléréséhez, de a szervezet rövid és hosszú távú stratégiáját már kevésbé ismerik ezen a szinten. Ez arra enged következtetni, hogy 
a felső-vezetés tisztábban látja a célokat, és nem fektet kellő súlyt azok megismertetésére és „lefelé” való kommunikálására az alsóbb vezetői szintek felé.

2. Az innovativitás témakör átlagértékei a felsővezetői szinten magasak, a közép és operatív szint átlagai közel azonos szintüek $(6,5 ; 4,6 ; 4,5)$. A közép és operatív szint átlagait a kockázatvállalásra vonatkozó kérdés átlagai rontották leginkább $(4,3 ; 4,2)$, ami egy mezőgazdasági szervezet esetében érthető, hiszen a számos folyamatosan jelen lévő kockázati tényező mellé nem szívesen vállal újabb kockázati elemeket a vezetés.

3. A vezetés témakörben, azaz a közvetlen fönökkel való kapcsolatra vonatkozóan mindegyik vezetői szintnél magas átlagértékeket kaptam $(6,7 ; 5$; 5,4). A szervezetet tehát a jól müködő vezetőbeosztott kapcsolatok jellemzik a teljesítménnyel kapcsolatos szóbeli visszajelzések rendszeresek.

4. Az együttmüködés témakörben a munkatársak közötti együttmüködésre vonatkozó kérdésnél magas átlagértékeket kaptam $(6 ; 5,8 ; 5)$; a közép és operatív vezetők szerint javítandó terület azonban a szervezeti egységek közötti együttmüködés és a konfliktusok kezelési módja $(4,5 ; 4,1)$.

5. A kommunikáció témakörében kaptam az egyik legalacsonyabb átlagértékeket, különös tekintettel a közép és operatív vezetői szinteken $(4,7 ; 4,5)$. A témán belüli kérdéseket egyenként vizsgálva a válaszokból kitűnik, hogy a szervezet formális információs csatornái (értekezletek, jelentések, vezetői tájékoztatók stb.) elégségesek és jól müködnek. A közép és operatív vezetők átlagát a 24-es kérdésre vonatkozó válaszok rontják leginkább: Az emberek általában nyíltan, bátran, öszintén elmondják véleményüket, javaslataikat a vállalatnál $(3,8 ; 4)$. Ez az eredmény valószínűsíthetően összefüggésben van a vezetési stílussal: az autokratikus vezetési stílus gátló tényezője lehet a szervezeten belüli öszinte, nyílt vélemény-nyilvánításnak.

6. A motiváció területén kaptam az összes témakör közül a legalacsonyabb átlageredményeket $(5,9$; $4,8 ; 3,9)$. Az egyes kérdésekre adott válaszokat külön vizsgálva azt találtam, hogy mindhárom vezetői szinten alapvetö probléma, hogy a vezetők nem látnak a munkájukból adódó karrierlehetőségeket a cégen belül (29-es kérdés átlagai: 4; 3,8; 3,8). A másik szembetünő probléma, hogy mindhárom vezetői szint a piaci viszonyokhoz képest is alacsonynak tartja a fizetését $(5,3 ; 4 ; 3)$. Ezt az eredményt nyilvánvalóan külső tényező okozhatja, magyarázható a vállalat földrajzi elhelyezkedésével. Ugyanakkor a munkakörülményeket (infrastruktúra, higiéniai feltételek) mindhárom vezetői szint megfelelőnek tartja.

7. Az alacsony motivációs értékek mellett az elkötelezettség témakörében születtek a legmagasabb átlageredmények $(6,6 ; 6,2 ; 6,1)$, és a szórás is itt a legkisebb. Ez az eredmény azt jelzi, hogy a vezetők sajátjuknak tekintik a céget és legjobb tudásuknak megfelelően tevékenykednek a mindennapok során, ami komoly érték a szervezetben.

8. A rugalmas, tanuló szervezet témakör átlageredményeit tekintve $(6,5 ; 5,1 ; 4)$ az tapasztalható, hogy a felső és operatív szint átlagai között szignifikáns különbség tapasztalható. Az operatív vezetői szintről kapott válaszok arra utalnak, hogy a tudásmenedzsment, azaz az információáramlás és tudásmegosztás szintén javítandó területe a cégnek.

IRODALOM

Beckhard-Harris (1989): Organizational Transitions. Addison Wesley

Earl, B. (1999): A társadalomtudományi kutatás gyakorlata. Balassi Kiadó, Budapest

French, W. L.-Bell, C. H. J. (1995): Organization Development. Prentice Hall

Harvey-Brown (1988): An Experiential Approach to OD. Prentice Hall N. Y.

Senge, P. (1998): Az 5. Alapelv. A tanuló szervezet kialakításának elmélete és gyakorlata. HVG

Szijjártó A. (1973): A vezetők helyzete és munkájuk megszervezésének néhány vonása a nagygazdaságainkban. Agrárgazdasági Kutató Intézet, Budapest

Trompenars, F. (1993): Riding the Wawes of Culture. Nicholas Brealey Publ. London

Társasági Ismertetők (belső) (1998): Állami Privatizációs és Vagyonkezelő Rt. 